\title{
New Records of Horsehair Worms (Nematomorpha) from India and a Summary of All Known Indian Species
}

\author{
Arun K. Yadav ${ }^{1}$, Dimos Khynriam ${ }^{2}$, Limatemjen ${ }^{3}$ and Andreas Schmidt-Rhaesa ${ }^{4, *}$ \\ 1 Department of Zoology, North-Eastern Hill University, Shillong 793022, India; akynehu@hotmail.com \\ 2 North Eastern Regional Centre, Zoological Survey of India, Shillong 793003, India; dkhyn@rediffmail.com \\ 3 Department of Zoology, Kohima Science College (Autonomous), Jotsoma, Nagaland 797002, India; \\ lima5lcr@gmail.com \\ 4 Centrum für Naturkunde, University Hamburg, Martin-Luther-King-Platz 3, 20146 Hamburg, Germany \\ * Correspondence: andreas.schmidt-rhaesa@uni-hamburg.de
}

Received: 22 September 2020; Accepted: 29 October 2020; Published: 9 November 2020

\begin{abstract}
Twenty-one species of the phylum Nematomorpha from India have been described. In this paper, Acutogordius sulawensis is reported for the first time in this country, with new locality records of some Chordodes, Gordius and Acutogordius species from the north-east region of India. The total number of nematomorph species now known from India is thus raised to twenty-two species. This paper supplements information about nematomorph species added to the Indian fauna after 2004.
\end{abstract}

Keywords: Gordiida; biodiversity; Acutogordius

\section{Introduction}

Around 360 species of Nematomorpha are known today [1]. New species are described constantly, but the geographical coverage of records is still very fragmentary. More intensive sampling often reveals an increase in records. One of these countries is India, where, until 2004, only 13 species of Gordiida (the terrestrial/freshwater Nematomorpha) and one undetermined Gordius were known [2]. With one exception and one additional undetermined Gordius species, all Indian gordiid species were reported prior to 1912. Moreover, till 2004, the documentation of several Indian gordiids was either not satisfactory or needed a proper reinvestigation, given the many taxonomic ambiguities [2]. However, after a long period of discontinuity, this phylum received renewed interest from researchers in India. First, Schmidt-Rhaesa and Yadav (2004) reported the fourteenth gordiid species in India, Chordodes cf. furnessi (Montgomery, 1898), which also constituted the first appropriate investigation of a nematomorph species in India, using high-resolution observations of specimens by scanning electron microscopy (SEM). Subsequently, between 2004 and 2017, seven further nematomorph species were newly described or newly recorded in this country, which took the number of nematomorph species in India to twenty-one [3-8]. The new additions in the Indian nematomorph fauna were made possible because of the renewed interest of researchers, especially from North-East India, their regular collaborations with expert scientists in this group, and also because of a better understanding of several structures that are considered important for species identification in these organisms. In fact, species in this phylum differ only in a few macroscopic characteristics, but the main characteristics important for the identification are fine structural details of the cuticle, which very often bear different types of raised structures called areoles. Additionally, several other structures present in the posterior end of male specimens are also considered taxonomically important [1]. In general, various surface structures in this group can be better elucidated using scanning electron microscopy, which allows a more thorough and detailed identification of the respective species [1]. 
India is a vast country, consisting of a broad range of climatic regions. Considering this, only less than two dozen gordiid species are known in India at present; there seems a high likelihood that the region is still under-sampled, and many more endemic or interesting gordiid species can be expected from this country.

In the line of our ongoing work on the biodiversity of Indian nematomorphs, some additional specimens of gordiids were collected from two states of North-East India in recent years. Upon careful observation, some of these specimens turned out to be interesting. In this paper, we report for the first time the occurrence of Acutogordius sulawensis Schmidt-Rhaesa \& Geraci (2006) from India and also discuss new locality records of Acutogordius, Chordodes and Gordius species in the north-east region of India. Further, we also update the existing checklist of Indian nematomorph species [2] to add the most recent reports.

\section{Materials and Methods}

The material for this study was collected on several occasions between December 2012 and October 2018 by hand from different aquatic habitats in the states of Meghalaya and Nagaland in India. Immediately after collection, specimens were stored in $70 \%$ ethanol. For scanning electron microscopy, pieces $0.5-1 \mathrm{~mm}$ in length were dissected from the anterior end and midbody. Moreover, the entire posterior end of male specimens was cut off approximately $1 \mathrm{~mm}$ from the posterior tip. The body fragments were then dehydrated in an increasing ethanol series, critical point dried with a Leica EM CPD 300 and coated with platin in a Polaron Range sputter coater. Observations were made using a LEO scanning electron microscope (SEM) 1524 at the Centrum für Naturkunde, University of Hamburg and JSM-6360 (JEOL) at NEHU, Shillong. Digital images of selected body regions were taken. Measurements are given in millimeters. The specimens were deposited in two museums. The SEM samples were deposited in the Zoological Museum in Hamburg, Germany (abbreviation $\mathrm{ZMH}$ ), which is part of the Leibniz Institute for Biodiversity Monitoring. The remaining parts of the specimens in ethanol were deposited in the collection of the Zoological Survey of India, North Eastern Regional Centre, Shillong, India (abbreviation IV/NERC/ZSI). Accession numbers are given in the Results section.

\section{Results}

\subsection{Acutogordius sulawensis Schmidt-Rhaesa \& Geraci, 2006}

Material investigated. Single male specimen from Ummluh river, Nongkhyllem Wild Life Sanctuary, Lailad, Ri-Bhoi district, Meghalaya, altitude 219 m; 25 55'39.5" N; 91 46'41.1" E; Date of collection 04 December 2012; Collector Dimos Khynriam and collector group. Accession numbers: ZMH V13463, IV/NERC/ZSI 314.

Description. The specimen is $145 \mathrm{~mm}$ long and light brown in color. A brown collar is present in the head region. The cuticular surface is smooth; areoles are not present (Figure 1A). In the posterior end, two tail lobes are present; the diameter of the worm decreases distinctly in the region of the tail lobes compared to the remaining body (Figure 1B). In the posterior end, the semi-circular postcloacal crescent extends slightly onto the tail lobes (Figure 1B). There are scattered fine bristles on the ventral side of the posterior end that extend along the postcloacal crescent and further posterior onto the tail lobes (Figure 1B,C). On the ventral side of the tail lobes, close to the inner edge, the concentration of bristles is highest (Figure 1B,C). Few bristles are present on the inner side of the tail lobes in its posterior part, whereas the anterior region is free of bristles and shows a slight patterning of areole-like structures (Figure 1B). 

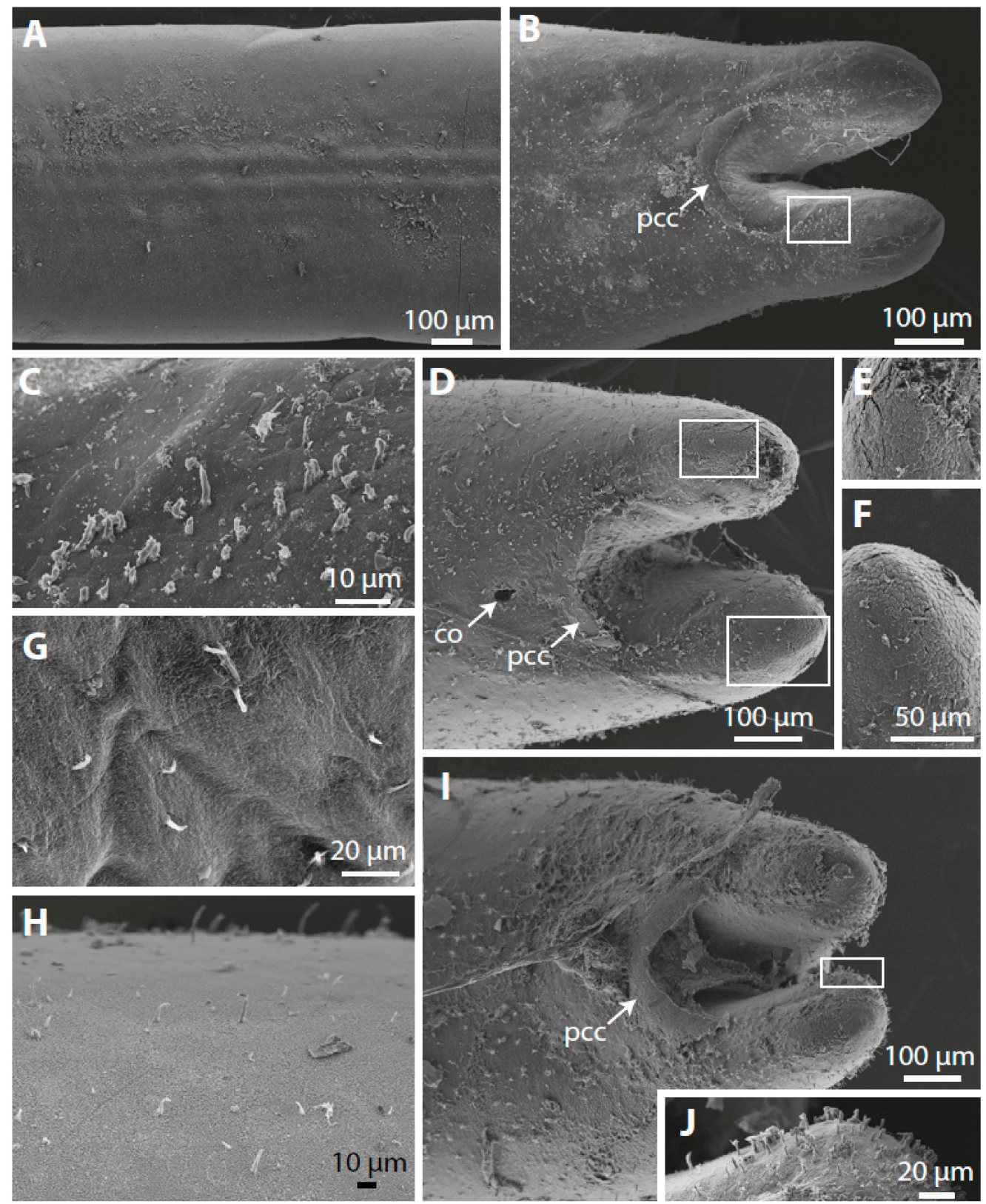

Figure 1. A-C. Acutogordius sulawensis. A. Cuticular surface. B. Ventral view of posterior end with postcloacal crescent (pcc). Square indicates position of magnification in Figure 1C. C. Bristles on the ventral side of one tail lobe. D-G. Acutogordius sp. 1. D. Ventral view of posterior end, co = cloacal opening. Squares indicate position of magnifications in Figure 1E and 1F. E, F. Areas with areoles on the tip of the tail lobes. G. Fine bristles on the cuticular surface. H-J. Acutogordius sp. 2. H. Bristles on the cuticular surface. I. Posterior end, square indicates position of magnification in figure J. J. Bristles on the tip of one tail lobe. A-C from ZMH V13463, D-G from ZMH V13469, H-J from ZMH V13470.

Remarks. The tapering posterior end clearly shows that this specimen belongs to the genus Acutogordius. There are not many diagnostic characteristics that help to distinguish the species in this genus from each other, but the combination of a smooth cuticle with the pattern of bristles extending over the postcloacal crescent and being concentrated on the ventral side of the tail lobes corresponds with the description of the species A. sulawensis, which has been described from Sulawesi, Indonesia [9]. 


\subsection{Acutogordius $s p .1$}

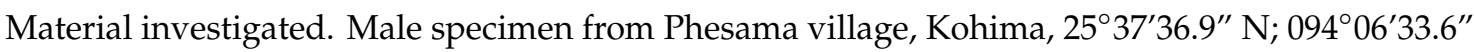
E; Date of collection 10 October 2018; Collector Limatemjen. Accession numbers: ZMH V13469, IV/NERC/ZSI 320.

Description. The specimen is $345 \mathrm{~mm}$ in length and light brown in color. The body cuticle is smooth, with few fine bristles (Figure 1G). In the posterior end, the tail lobes are short and tapering (Figure 1D). The postcloacal crescent is roughly semi-circular. The round cloacal opening is positioned $50 \mu \mathrm{m}$ from the anterior edge of the postcloacal crescent. The crescent appears directly over the point of bifurcation of the tail lobes. Patches of areole-like structures are present on the ventral side of the tips of the tail lobes (Figure 1D-F). The cuticle on the inner side of the tail lobes, especially in the anterior region, is also slightly structured into areole-like elevations (Figure 1D). Bristles are present, as far as could be observed, on the outer sides and on the posterior tips of the tail lobes.

Remarks. The patches of areoles in the terminal region of the tail lobes have been described only from A. protectus Schmidt-Rhaesa \& Geraci, 2006, a species from Madagascar [9]. The pattern of bristles differs between $A$. protectus and the Indian specimen. Whereas $A$. protectus has many bristles on the ventral side of the entire posterior end, extending roughly in two broad bands, the Indian specimen has bristles mainly in the lateral and terminal regions. The ventral side is slightly covered by particles, making the exact observation of bristles difficult, but it seems that a complex pattern of bristles as in A. protectus is not present.

\subsection{Acutogordius sp. 2}

Material investigated. Male specimen from Phezu Hills Jotsoma, District Kohima, 2539'51.7” N; 094 04'38.5" E; Date of collection 15 September 2018; Collector: Limatemjen. Accession numbers: ZMH V13470, IV/NERC/ZSI 321.

Description. The specimen is $165 \mathrm{~mm}$ in length and light brown in color. The smooth body cuticle is covered with scattered fine bristles (Figure 1H). In the posterior end, the tail lobes are short and tapering (Figure 1I). The postcloacal crescent is semi-circular and extends onto the tail lobes. The cloacal opening is covered by sperm or other material. Bristles are present on the lateral side of the posterior end and especially of the tail lobes and on their tip (Figure 1I,J). Further bristles, e.g., on the ventral side, may be present, but they could not be observed with certainty due to the presence of some polluting material.

Remarks. Fine bristles on the cuticle were not reported from most of the species, but in the older records, this may be due to not using sufficient magnification methods such as SEM. Bristles on the cuticle are present, e.g., in A. finni Schmidt-Rhaesa \& Schwarz, 2016, described from the Philippines [10], and two closely similar-looking specimens of this species were recorded from India [6]. The new specimens, however, differ in the pattern of bristles in the posterior end. Whereas A. finni has a concentration of bristles on the inner edge of the ventral side of the tail lobes, specimen 2 has a concentration of bristles on the lateral and posterior sides of the tail lobes.

\subsection{Chordodes combiareolatus Schmidt-Rhaesa, Limatemjen E Yadav, 2015}

Material investigated. Five female specimens from Ummluh river, Nongkhyllem Wild life Sanctuary, Lailad, Ri-Bhoi district, Meghalaya, altitude 219 m; 25 55'39.5” N; 91 $46^{\prime} 41.1^{\prime \prime}$ E; Date of collection 04 December 2012; Collector: Dimos Khynriam and collector group. Accession numbers: ZMH V13464-V13468, IV/NERC/ZSI 315-319.

Description. The specimens measure between 155 and $360 \mathrm{~mm}$ in length. The anterior end is tapering; areoles cover the entire region (Figure 2A). The posterior end is slightly swollen (Figure 2B). The terminal cloacal opening is surrounded by an area of smooth cuticle, followed by an area with fine radial striation (Figure 2D). At a distance of about 140-150 $\mu \mathrm{m}$ from the cloacal opening, a number of bristles are present (Figure 2D). The simple areoles on the cuticular surface have a tuft of short 
bristles. This tuft is large on areoles in the anterior end (Figure 2C) and much smaller on areoles of the remaining body (Figure 2F). Tubercle and thorn areoles are present (Figure 2F,G). Tubercle areoles occur as "single" and "combined" areoles, meaning that either the tubercle originates from a socket ("single") or that it originates from the side of what otherwise is a simple areole ("combined"; Figure 2H). Clusters of crowned areoles have moderately long apical bristles (Figure 2F). In the midline, presumably the ventral midline, crowned areoles with long apical filaments are present (Figure 2E,I). In the anterior end, crowned areoles are not present; the cuticle is densely covered with simple areoles (Figure 2C). Between the areoles are several isolated tubercles (Figure 2C).
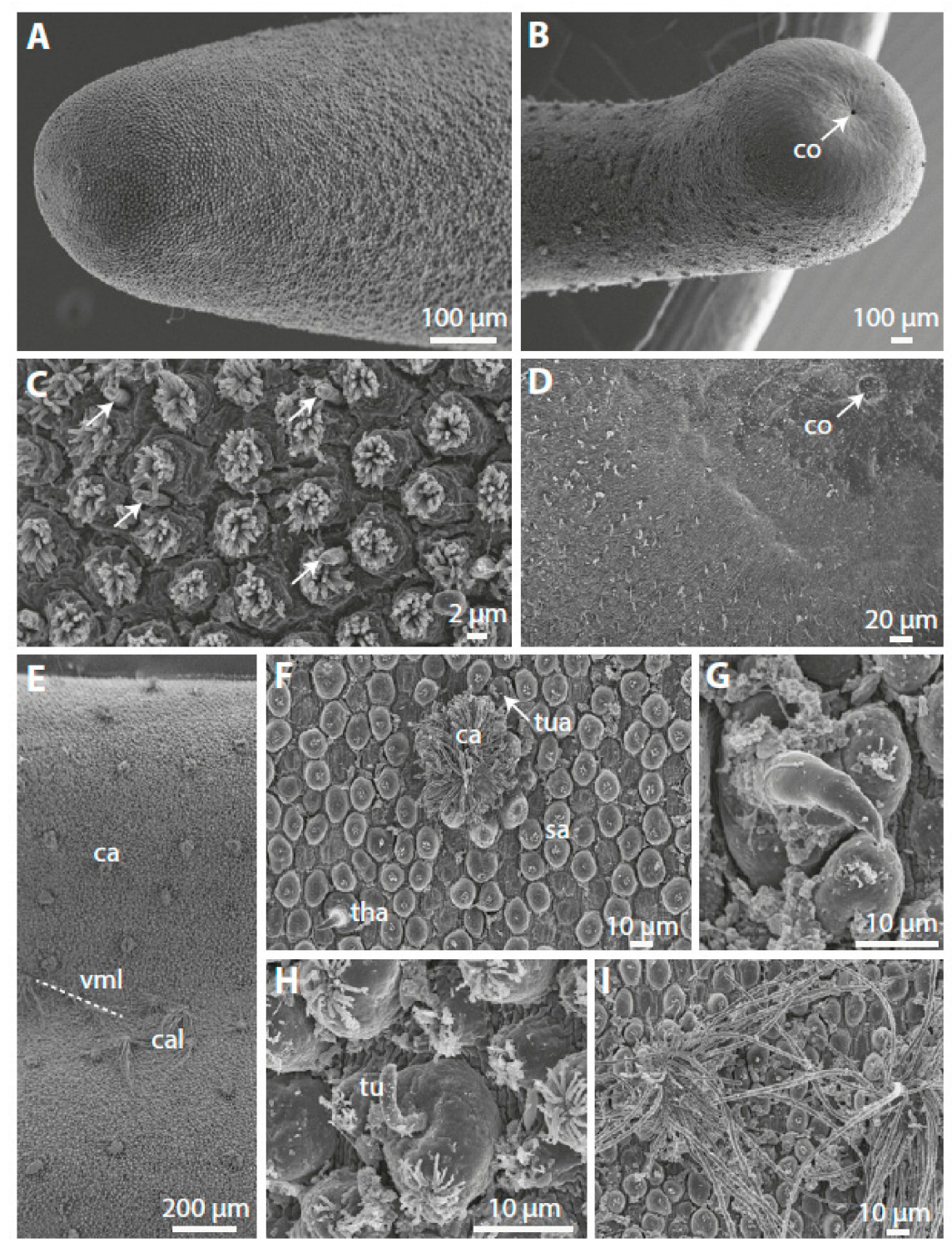

Figure 2. Chordodes combiareolatus. A. Overview of anterior end. B. Overview of posterior end with terminal cloacal opening (co). C. Simple areoles with large tuft and isolated tubercles (arrows) in the anterior end. D. Distribution of bristles and of regions with smooth cuticle and fine striation around the cloacal opening (co). E. Cuticle of the entire circumference spread flat, showing clusters of crowned areoles with long apical filaments (cal) along the ventral midline ( $\mathrm{vml}$ ) and clusters of crowned areoles with shorter filaments (ca) on the remaining cuticle. F. Overview of areolar structures: crowned areoles (ca), simple areoles (sa), tubercle areoles (tua) and thorn areoles (tha). G. Magnification of thorn areole. H. Combined areole of simple and tubercle areole. I. Magnification of crowned areoles with long apical filaments. A-C from ZMH V13465, D, E from ZMH V13466, F-I from ZMH V13467. 
Remarks. The cuticular characteristics described correspond well with the description of the species C. combiareolatus, described from Viswema, Nagaland by [5], with the report of a further specimen from Longjang, Nagaland by [7]. The presence of combined simple/tubercle areoles is considered to be characteristic for this species. This is the third report of this species in India; all reports are from Eastern India.

\subsection{Gordius $s p$.}

Material investigated. Three female specimens from Tuensang (Nagaland), 26 $16^{\prime} 48^{\prime \prime} \mathrm{N}$; 94 $49^{\prime} 48^{\prime \prime}$ E; Date of collection 13 August 2017; Collector Limatemjen. Accession numbers: ZMH V13471-V13473, IV/NERC/ZSI 322-324; one female specimen from Longjang (Nagaland), $26.442015^{\circ} \mathrm{N}$; 94.53849 ${ }^{\circ}$ E; Date of collection 24 September 2015; Collector: Lanu Pongen. Accession numbers: ZMH V13474, IV/NERC/ZSI 325; one male specimen from Longjang (Nagaland); $26.442015^{\circ} \mathrm{N} ; 94.53849^{\circ}$ E; Date of collection 24 September 2015; Collector Lanu Pongen. Accession numbers: ZMH V13475, IV/NERC/ZSI 326.

Description. The females are 142, 175, 215 and $230 \mathrm{~mm}$ long; the male measures $165 \mathrm{~mm}$ in length. The cuticle in all specimens is smooth (Figure $3 \mathrm{~A}-\mathrm{C}$ ). The covering by some detritus and a partly shrunken and folded cuticle make observation not always easy. Partly, a striation pattern of crossing lines at an angle of $60^{\circ}$ and $120^{\circ}$ in relation to the longitudinal axis of the animal is present (Figure 3B,C). The posterior end of the male has two lobes but is completely covered by algae and no further details could be observed.
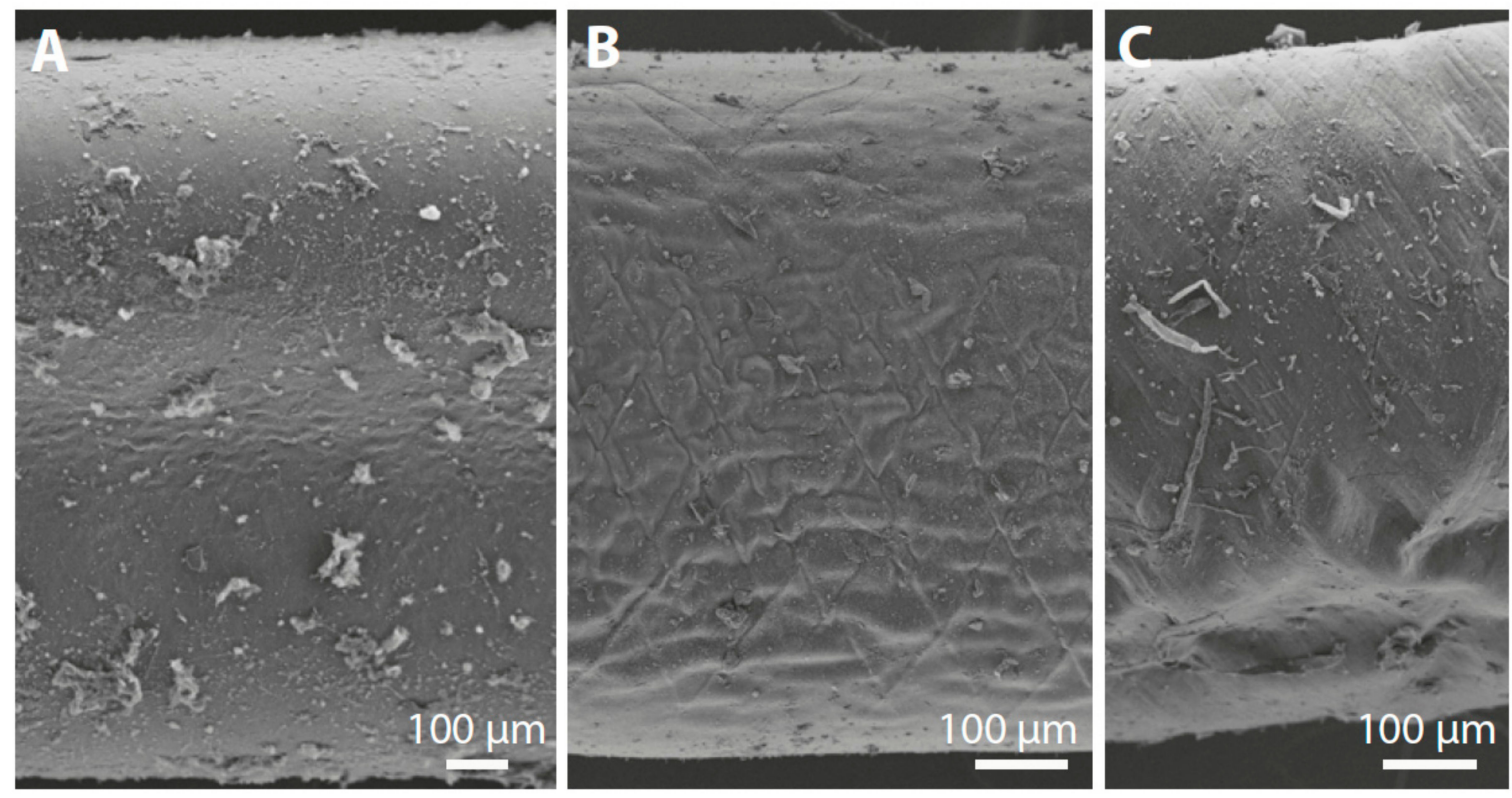

Figure 3. A-C. Gordius sp., cuticular surface of three specimens. Note striations in B and C caused by internal fibers within the cuticle. A from ZMH V13473, B from ZMH V13474, C from ZMH V13475.

Remarks. A smooth cuticular surface has so far only been reported in some Gordius species [11]; therefore, the reported specimens certainly belong to this genus. As several species have a smooth cuticle and as further diagnostic characteristics are absent, especially in female specimens, it is not possible to identify the specimens to species level. Gordius specimens have been reported in India on some occasions. The older reports with the assignment to species level should be treated with some care. For example, Gordius robustus Leidy, 1851 is reported by Rajaram \& Rajulu [12], but this species is restricted to North America [13]. DNA investigations in this species have also shown that Gordius specimens with a smooth cuticle form a complex of cryptic species [14]. Nevertheless, the new records of Gordius sp. are new records for Nagaland, where no Gordius species has been reported so far. 


\section{Discussion}

With the newly reported species Acutogordius sulawensis, the number of reported species from India is raised to 22 (see Table 1). These 22 species belong to seven genera. The genus Beatogordius has been recently reported with one species, B. nagalandensis Yadav, Schmidt-Rhaesa \& Limatemjen, 2015 [7]. This report is biogeographically interesting, because Beatogordius is distributed mainly on continents of former Gondwana [see 7]. The genus Parachordodes is reported with two species [13]. One of these, P. pustulosus (Baird, 1853), has a broad distribution from Europe to China [1], but the report from India [15] is just a brief note without description or documentation. The other species, $P$. roccatii, is newly described, but the description is not supplied by figures [15]. Only one type of areole is described, whereas in the genus Parachordodes, two types are present [1]. Parachordodes roccatii (Camerano, 1912) likely belongs to the genus Gordionus but has not yet been transferred due to the lack of images or reinvestigation [1]. The genus Gordionus is represented in India by one species, G. kaschgaricus (Camerano, 1897), but again the record of this species is very brief and without figures [15]. Finally, the genus Paragordius is represented with one female specimen of P. stylosus (Linstow, 1883), reported also by just a brief note with a minimalistic description and no figures [15]. As females of the genus Paragordius are easy to recognize due to their trilobed posterior end, at least the genus record is quite certain.

Table 1. Reports of nematomorph species from India, modified from the previous checklist from Schmidt-Rhaesa \& Yadav (2004).

\begin{tabular}{|c|c|c|}
\hline Species & Distribution & Reference \\
\hline Acutogordius doriae (Camerano, 1890) & $\begin{array}{l}\text { Bagracote, Siliguri, Darjiling (West } \\
\text { Bengal); Someshwar (Uttarakhand) }\end{array}$ & {$[15,16]$} \\
\hline Acutogordius finni Schmidt-Rhaesa \& Schwarz, 2016 & Aizawl (Mizoram) & [6] \\
\hline Acutogordius sulawensis Schmidt-Rhaesa \& Geraci, 2006 & Lailad (Meghalaya) & This study \\
\hline Acutogordius species 1 & Phesama (Nagaland) & This study \\
\hline Acutogordius species 2 & Jotsoma (Nagaland) & This study \\
\hline $\begin{array}{c}\text { Beatogordius nagalandis Yadav, Schmidt-Rhaesa \& } \\
\text { Limatemjen, } 2017\end{array}$ & Viswema (Nagaland) & [7] \\
\hline $\begin{array}{l}\text { Chordodes combiareolatus Schmidt-Rhaesa, Limatemjen \& } \\
\text { Yadav, } 2015\end{array}$ & Viswema, Longjang (Nagaland) & {$[5,7]$, this study } \\
\hline Chordodes cf. furnessi (Montgomery, 1898) & $\begin{array}{l}\text { Shillong (Meghalaya) Longjang } \\
\text { (Nagaland) }\end{array}$ & {$[2,7]$} \\
\hline Chordodes lasuboni Schmidt-Rhaesa \& Yadav, 2013 & Shillong (Meghalaya) & [4] \\
\hline Chordodes liguligerus (Römer, 1895) & Calcutta (West Bengal) & [17] \\
\hline Chordodes mizoramensis Schmidt-Rhaesa \&Lalramliana, 2011 & Mamit (Mizoram) & [3] \\
\hline Chordodes moutoni Camerano, 1895 & $\begin{array}{l}\text { Shillong (Meghalaya), Viswema } \\
\text { (Nagaland) }\end{array}$ & {$[4,5]$} \\
\hline Chordodes pollonerae (Camerano, 1912) & Assam & [15] \\
\hline Chordodes siamensis (Camerano, 1903) & Assam & [16] \\
\hline Chordodes tjorvenae Schmidt-Rhaesa \& Lalramliana, 2016 & Lungpuk (Mizoram) & [6] \\
\hline Chordodes sp. & Sala river, Tuichang river (Mizoram) & [6] \\
\hline Gordionus kaschgaricus (Camerano, 1897) & $\begin{array}{l}\text { Shembaganur, Palni Hills, Madras } \\
\text { (Tamil Nadu) }\end{array}$ & [15] \\
\hline Gordius fulgur (Baird, 1861) & Badarpur (Assam) & [15] \\
\hline Gordius paronae (Camerano, 1903) & $\begin{array}{c}\text { Darjiling (West Bengal), Sikkim, Tura } \\
\text { (Meghalaya) }\end{array}$ & [16] \\
\hline Gordius robustus (Leidy, 1851) & Coimbatore area (Tamil Nadu) & [12] \\
\hline Gordius shaerura (Baird, 1853) & Khasi Hills (Meghalaya) & [18] \\
\hline Gordius zavattarii (Camerano, 1908) & Darjiling (West Bengal) & [15] \\
\hline Gordius sp. & Different Districts of Mizoram & [19] \\
\hline Gordius sp. & Shillong (Meghalaya) & [8] \\
\hline Gordius sp. & Darjiling (West Bengal) & [20] \\
\hline Gordius sp. & Kohima (Nagaland) & This study \\
\hline Parachordodes pustulosus (Baird, 1853) & Siliguri, Cachar (Assam) & [15] \\
\hline Parachordodes roccatii (Camerano, 1912) & Majkhali (Uttarakhand) & [15] \\
\hline Paragordius stylosus (Linstow, 1883) & Delhi, Punjab & [15] \\
\hline
\end{tabular}


The three genera with more abundant records are Chordodes, Gordius and Acutogordius. The genus Chordodes is species-rich (about 100 species) and occurs in tropical and subtropical regions worldwide [21]. The genus Gordius is also distributed worldwide [11]. Quite interesting from a biogeographical perspective is the genus Acutogordius. The 12 species of this genus are either described from regions originating from the Gondwana continent (South America, Australia, Madagascar, India) or from the Indo-Malayan ecozone. Only the record of A. americanus De Miralles \& De Villalobos, 1998 from Costa Rica [22] goes beyond these borders; this is probably caused by a spreading of Acutogordius from South America northwards.

As is evident from the checklist, all recent additions to the Indian gordian fauna have been made from the north-east region, and, therefore, other regions of the country also deserve a proper sampling. In general, diversity in Asia has received comparatively little attention, and except for Japan, other countries, including India, are considered more or less under-sampled [23]. The gordiid collections, which are often accidental in nature, do not always reach the hands of experts; besides, easy access to electron microscopical facilities is also an important issue. To conclude, more detailed studies are required on this phylum in India, which will not only reveal a true picture of nematomorph fauna in the country but may also reveal further interesting information about endemic species.

Author Contributions: A.K.Y. and A.S.-R. contributed equally to the practical examination of the specimens reported here and both authors have written parts of the text and revised the parts written by the other. D.K. and L. collected specimens and revised the manuscript. All authors have read and agreed to the published version of the manuscript.

Funding: This research received no external funding.

Acknowledgments: SEM support from Renate Walter at Hamburg and by SAIF-NEHU, Shillong is highly appreciated. We thank two anonymous reviewers for their valuable comments.

Conflicts of Interest: The authors declare no conflict of interest.

\section{References}

1. Schmidt-Rhaesa, A. Nematomorpha. In Handbook of Zoology. Gastrotricha, Cycloneuralia and Gnathifera; Schmidt-Rhaesa, A., Ed.; Volume 1: Nematomorpha, Priapulida, Kinorhyncha and Loricifera; De Gruyter: Berlin, Germany, 2013; pp. 29-145.

2. Schmidt-Rhaesa, A.; Yadav, A.K. First report of Chordodes cf. furnessi (Nematomorpha) from a praying mantid in India with a note on Indian nematomorph species. Curr. Sci. 2004, 86, 1023-1027.

3. Schmidt-Rhaesa, A.; Lalramliana. Chordodes mizoramensis (Nematomorpha, Gordiida), a new species of horsehair worm from Mizoram, North-East India. ZooKeys 2011, 75, 1-8. [CrossRef] [PubMed]

4. Schmidt-Rhaesa, A.; Yadav, A.K. One new species and a new record of the genus Chordodes (Nematomorpha: Gordiida) from North-East India. Zootaxa 2013, 3693, 293-300. [CrossRef] [PubMed]

5. Schmidt-Rhaesa, A.; Limatemjen; Yadav, A.K. Chordodes combiareolatus, a new species of horsehair worms (Nematomorpha) from Nagaland, India, with further comments on Chordodes moutoni. Zootaxa 2015, 27, 202-210.

6. Schmidt-Rhaesa, A.; Lalramliana. New records of Indian Nematomorpha, with the description of a new species from the genus Chordodes. Zootaxa 2016, 4158, 272-280. [CrossRef] [PubMed]

7. Yadav, A.K.; Schmidt-Rhaesa, A. Limatemjen First report of the Gondwana genus Beatogordius from India, with further records of two Chordodes species (Gordiida, Nematomorpha). Zookeys 2017, 643, 53-61. [CrossRef]

8. Yadav, A.K.; Schmidt-Rhaesa, A.; Laha, R.; Sen, A. On the recovery of horsehair worms, Gordius sp. (Nematomorpha: Gordiida) from pork in Shillong, India. J. Parasit. Dis. 2017, 41, 302-304. [CrossRef]

9. Schmidt-Rhaesa, A.; Geraci, C.J. Two new species of Acutogordius (Nematomorpha), with a brief review of literature data of this genus. Syst. Biodivers. 2006, 4, 427-433. [CrossRef]

10. Schmidt-Rhaesa, A.; Schwarz, C.J. Nematomorpha from the Philippines, with description of two new species. Zootaxa 2016, 4158, 246-260. [CrossRef]

11. Schmidt-Rhaesa, A. Considerations on the genus Gordius (Nematomorpha, horsehair worms), with the description of seven new species. Zootaxa 2010, 2533, 1-35. [CrossRef]

12. Rajaram, B.; Rajulu, G.S. A study of the cuticle of Gordius robustus, a nematomorph worm. Acta Histochem. $1975,54,257-271$. 
13. Schmidt-Rhaesa, A.; Hanelt, B.; Reeves, W. Redescription and compilation of Nearctic freshwater Nematomorpha (Gordiida), with the description of two new species. Proc. Acad. Nat. Sci. Phila. 2003, 153, 77-117. [CrossRef]

14. Hanelt, B.; Schmidt-Rhaesa, A.; Bolek, M.G. Cryptic species of hairworm parasites revealed by molecular data and crowdsourcing of specimen collections. Mol. Phylogenetics Evol. 2015, 82, 211-218. [CrossRef]

15. Camerano, L. Gordiens du Musée Indien. Rec. Indian Mus. 1912, 7, 215-216.

16. Camerano, L. Gordiens du Musée Indien. Rec. Indian Mus. 1908, 2, 112-117.

17. Römer, F. Die Gordiiden des Naturhistorischen Museums in Hamburg. Zool. Jb. Syst. 1895, 8, 790-803.

18. Baird, W. Descriptions of some new species of Entozoa from the collection of the British Museum. Proc. Zool. Soc. Lond. 1853, 18-25.

19. Patra, G.; Borthakur, S.K.; Ghosh, S.; Alam, S.S.; Lalliankimi, H.; Lalrinkima, H. Morphological and molecular characterization of Gordius, a horse hairworm recovered from cricket. Asian Pac. J. Trop. Dis. 2017, 7, 422-425. [CrossRef]

20. Dasgupta, R.; Khawas, P. A gordiid worm in Darjeeling. J. Bombay Nat. Hist. Soc. 1986, 5, 160-162.

21. Schmidt-Rhaesa, A.; de Villalobos, L.C.; Zanca, F. Summary of Chordodes species (Nematomorpha, Gordiida), with a discussion of their diagnostic characters. Verh. Naturwiss. Ver. Hamburg 2008, 44, 37-114.

22. De Miralles, D.A.B.; de Villalobos, L.C. Dos nuevas especies y una nueva combinacion para el genero Acutogordius (Nematomorpha: Gordiidae). Neotropica 1998, 44, 75-79.

23. Poinar, G.O. Global diversity of hairworms (Nematomorpha: Gordiaceae) in freshwater. Hydrobiologia 2008, 595, 79-83. [CrossRef]

Publisher's Note: MDPI stays neutral with regard to jurisdictional claims in published maps and institutional affiliations.

(C) 2020 by the authors. Licensee MDPI, Basel, Switzerland. This article is an open access article distributed under the terms and conditions of the Creative Commons Attribution (CC BY) license (http://creativecommons.org/licenses/by/4.0/). 